\title{
PENGARUH FASILITAS KERJA DAN KARAKTERISTIK PEKERJAAN TERHADAP KEPUASAN KERJA DALAM UPAYA MENINGKATKAN KINERJA PEGAWAI DI KANTOR PELAYANAN PAJAK PRATAMA TEBING TINGGI
}

\author{
Sari Ulina Perangin-Angin \\ Universitras Islam Sumatera Utara \\ sariulina@gmail.com
}

\begin{abstract}
The formulation of the problem in this research is how the influence of work facility on job satisfaction. How influence of job characteristic on job satisfaction. How influence of work facility on employees performance. How influence of job characteristic on employees performance. How influence of work satisfaction on employees performance.The purpose of this research is for know influence of work facility on job satisfaction. How influence of job characteristic on job satisfaction. For know influence of work facility on employees performance. For know influence job characteristic on employees performance. For know influence work satisfaction on employees performance. The sample in this research is 95 employees, with data analysis technique used is path analize. The results of this research explain that work facility effect has a positive and significant on employee job satisfaction. Job Characteristic effect has a positive and significant on employee job satisfaction. Work facility effect has a positive and significant on employee performance. Job characteristic effect has a positive and significant on employee performance. Job satisfaction effect has a positive and significant on employee performance.
\end{abstract}

Keywords : Work facility, Job characteristic, Job satisfaction, Performance

ABSTRAK : Rumusan masalah dalam penelitian ini adalah bagaimana pengaruh fasilitas kerja terhadap kepuasan kerja. Bagaimana pengaruh karakteristik pekerjaan terhadap kepuasan kerja. Bagaimana pengaruh fasilitas kerja terhadap kinerja. Bagaimana pengaruh karakteristik pekerjaan terhadap kinerja. Bagaimana pengaruh kepuasan kerja terhadap kinerja. Tujuan penelitian ini adalah untuk mengetahui dan menganalisis pengaruh fasilitas kerja terhadap kepuasan kerja. Untuk mengetahui dan menganalisis pengaruh karakteristik pekerjaan terhadap kepuasan kerja. Untuk mengetahui dan menganalisis pengaruh fasilitas kerja terhadap kinerja. Untuk mengetahui dan menganalisis pengaruh karakteristik pekerjaan terhadap kinerja. Untuk mengetahui dan menganalisis pengaruh kepuasan kerja terhadap kinerja. Sampel dalam penelitian ini berjumlah 95 orang pegawai. Teknik analisis data dalam penelitian ini menggunakan analisis deskriptif dan analisis jalur. Hasil penelitian ini menjelaskan bahwa fasilitas kerja berpengaruh positif dan signifikan terhadap kepuasan kerja pegawai. Karakteristik pekerjaan berpengaruh positif dan signifikan terhadap kepuasan kerja pegawai. Fasilitas kerja berpengaruh positif dan signifikan terhadap kinerja pegawai. Karakteristik pekerjaan berpengaruh positif dan signifikan terhadap kinerja pegawai. Kepuasan kerja berpengaruh positif dan signifikan terhadap kinerja pegawai

Kata kunci : Fasilitas kerja, Karakteristik pekerjaan, Kepuasan kerja, Kinerja

\section{Pendahuluan}

Pegawai Kantor Pelayanan Pajak Pratama Tebing Tinggi merupakan salah satu sumber daya organisasi yang mempunyai nilai prakarsa dan memiliki peran penting dalam pemberdayaan sumber daya lainnya di dalam organisasi. Sistem pengelolaan Sumber Daya Manusia (SDM) yang tepat merupakan kunci keberhasilan organisasi untuk mencapai tujuannya. Oleh karena itu, agar tujuan dan sasaran organisasi dapat dicapai, perlu adanya perhatian yang lebih dari organisasi terhadap upaya-upaya dalam meningkatkan kinerja pegawai.

Birokrasi merupakan instrumen penting dalam masyarakat yang kehadirannya tak mungkin terelakkan dengan konsekuensi logis misi suci yaitu untuk mensejahterakan 
rakyatnya. Berkenaan dengan upaya pelayanan dan mewujudkan kesejahteraan rakyat, birokrasi publik memberikan andil yang relatif besar. Untuk mencapai tujuan yang mulia dari birokrasi, diperlukan kiranya pegawai yang handal dan cekatan dalam menangkap kebutuhan zaman yang semakin kompleks dewasa ini. Aparatur pemerintah yang mempunyai kejujuran, bisa menjadi suri tauladan bagi publik, memiliki kapasitas intelektual, kinerja, penguasaan teknologi,dan lain-lain. Sejumlah tuntutan kemampuan tersebut merupakan kebutuhan dalam pengembangan sumber daya manusia aparatur pemerintah dalam birokrasi publik di Indonesia. Colquitt at.al (2009:273), menyatakan kinerja adalah nilai dari seperangkat perilaku pegawai yang berkontribusi secara positif dan negatif untuk mencapai tujuan organisasi.

Faktor lain yang dapat mempengaruhi kinerja pegawai Kantor Pelayanan Pajak Pratama Tebing Tinggi adalah karakteristik pekerjaan. Studi empiris dari Wilson Bangun (2006) dan Firman (2011) menyatakan karakteristik pekerjaan berpengaruh positif terhadap kepuasan kerja, dan hasil peelitian dari Rizal Eka Affandi (2016) menyatakan karakteristik pekerjaan berpengaruh positif terhadap kinerja.

Variabel ketiga yang mempengaruhi kinerja pegawai Kantor Pelayanan Pajak Pratama Tebing Tinggi adalah kepuasan kerja. Studi empiris yang menyatakan kepuasan kerja berpengaruh positif terhadap kinerja diantaranya Isnan Munawirsyah (2017) dan Khoirun Aman at.al (2017). Hal ini sejalan dengan teori dari Goleman (2008:111) yang menyatakan bahwa kepuasan kerja adalah seperangkat perilaku kerja positif yang berakar pada kesadaran yang kental, keyakinan yang fundamental, disertai komitmen yang total pada paradigma kerja yang integral. Istilah paradigma di sini berarti konsep utama tentang kerja itu sendiri yang mencakup idealisme yang mendasari, prinsip-prinsip yang mengatur, nilainilai yang menggerakkan, sikap-sikap yang dilahirkan, standar-standar yang hendak dicapai, termasuk karakter utama, pikiran dasar, kode etik, kode moral, dan kode perilaku bagi para pemeluknya. Fenomena yang terjadi tentang kepuasan kerja pegawai Kantor Pelayanan Pajak Pratama Tebing Tinggi diantaranya masih ada pembagian tugas yang belum merata ke bawahan dari atasan sehingga menimbulkan ketidakpuasan pegawai dalam bekerja.

Adapun Tujuan penelitian ini adalah :

a. Untuk mengetahui dan menganalisis pengaruh fasilitas kerja terhadap kepuasan kerja pegawai di Kantor Pelayanan Pajak Pratama Tebing Tinggi.

b. Untuk mengetahui dan menganalisis pengaruh karakteristik pekerjaan terhadap kepuasan kerja pegawai di Kantor Pelayanan Pajak Pratama Tebing Tinggi

c. Untuk mengetahui dan menganalisis pengaruh fasilitas kerja terhadap kinerja pegawai di Kantor Pelayanan Pajak Pratama Tebing Tinggi.

d. Untuk mengetahui dan menganalisis pengaruh karakteristik pekerjaan terhadap kinerja pegawai di Kantor Pelayanan Pajak Pratama Tebing Tinggi.

e. Untuk mengetahui dan menganalisis pengaruh kepuasan kerja terhadap kinerja pegawai di Kantor Pelayanan Pajak Pratama Tebing Tinggi.

\section{Metode Penelitian \\ 2.1. Lokasi Penelitian}

Penelitian ini dilakukan di Kantor Pelayanan Pajak Pratama Tebing Tinggi. Jalan Sutoyo No. 32 Tebing Tinggi

\subsection{Populasi}

Menurut Sugiyono (2010:90) populasi adalah wilayah generasi yang terdiri dari atas objek/subjek yang mempunyai kualitas karakteristik tertentu yang disajikan oleh peneliti untuk dipelajari dan kemudian ditarik kesimpulannya. Berdasarkan defenisi tersebut, maka populasi dalam penelitian ini adalah para pegawai Kantor Pelayanan Pajak Pratama Tebing Tinggi yang berjumlah 97 orang, dimana Kepala Kantor dan peneliti tidak dimasukkan sebagai populasi dengan rincian sebagai berikut :

\subsection{Sampel}

Dengan teknik penarikan sampel secara total sampling, maka sampel dalam penelitian ini seluruh populasi yaitu 95 orang pegawai Kantor Pelayanan Pajak Pratama Tebing Tinggi. Sampel ini tidak termasuk kepala kantor dan peneliti 
Tabel 2

Definisi Operasional Variabel

\begin{tabular}{|c|c|c|c|c|}
\hline No & Defenisi Variabel & $\begin{array}{c}\text { Jenis } \\
\text { Variabel }\end{array}$ & Indikator & $\begin{array}{c}\text { Skala } \\
\text { Pengukuran }\end{array}$ \\
\hline 1. & $\begin{array}{l}\text { Fasilitas kerja merupakan kelengkapan kerja } \\
\text { yang harus dimiliki oleh organisasi. } \\
\text { Hasibuan (2008:54) }\end{array}$ & $\begin{array}{c}\text { Variabel } \\
\text { bebas }\end{array}$ & $\begin{array}{l}\text { 1) Kendaraan dinas } \\
\text { 2) Meja, kursi kerja } \\
\text { 3) IT dan ruang kerja } \\
\text { 4) Penerangan } \\
\text { Hasibuan (2008:61) }\end{array}$ & $\begin{array}{l}\text { Skala } \\
\text { Ordinal }\end{array}$ \\
\hline 2. & $\begin{array}{l}\text { Karakteristik pekerjaan (job characteristic } \\
\text { models) merupakan suatu pendekatan terhadap } \\
\text { pemerkayaan pekerjaan (job enrichment). } \\
\text { Handoko (2008:111) }\end{array}$ & $\begin{array}{l}\text { Variabel } \\
\text { bebas }\end{array}$ & $\begin{array}{l}\text { 1). Otonomi } \\
\text { 2). Identitas tugas } \\
\text { 3). Signifikansi tugas } \\
\text { 4). Umpan balik } \\
\text { Rivai }(2009: 217) \\
\end{array}$ & $\begin{array}{l}\text { Skala } \\
\text { Ordinal }\end{array}$ \\
\hline 3. & $\begin{array}{l}\text { Kepuasan kerja adalah seperangkat perilaku } \\
\text { kerja positif yang berakar pada kesadaran yang } \\
\text { kental, keyakinan yang fundamental, disertai } \\
\text { komitmen yang total pada paradigma kerja } \\
\text { yang integral. } \\
\text { Milkovich }(2008: 141)\end{array}$ & $\begin{array}{c}\text { Variabel } \\
\text { terikat }\end{array}$ & $\begin{array}{ll}\text { 1) Kepuasan } & \text { dengan } \\
\text { gaji } & \\
\text { 2) Kepuasa } & \text { dengan } \\
\text { promosi } & \\
\text { 3) Kepuasan } & \text { terhadap } \\
\text { atasan } & \\
\text { 4) Kepuasan } & \text { terhadap } \\
\text { pekerjaan } & \\
\text { Milkovich (2008:147) }\end{array}$ & $\begin{array}{l}\text { Skala } \\
\text { Ordinal }\end{array}$ \\
\hline 4. & $\begin{array}{l}\text { Kinerja pegawai merupakan hasil yang dicapai } \\
\text { oleh pegawai dalam melaksanakan tugas-tugas } \\
\text { yang dibebankan kepadanya yang didasarkan } \\
\text { atas kecakapan, kemudian pengalaman dan } \\
\text { keunggulan serta penggunaan waktu. } \\
\text { Hasibuan }(2008: 88) \text {. }\end{array}$ & $\begin{array}{c}\text { Variabel } \\
\text { terikat }\end{array}$ & $\begin{array}{l}\text { 1)Kuantitas } \\
\text { 2)Kualitas } \\
\text { 3)Kreativitas } \\
\text { 4)Standar profesional } \\
\text { Hasibuan (2008:95) }\end{array}$ & $\begin{array}{l}\text { Skala } \\
\text { Ordinal }\end{array}$ \\
\hline
\end{tabular}

\subsection{Uji Kualitas Data}

\subsubsection{Uji Validitas}

Suliyanto (2011:133), uji validitas digunakan untuk mengukur sah atau valid tidaknya suatu kuesioner. Suatu kuesioner dikatakan valid jika pertanyaan pada kuesioner mampu untuk mengungkapkan sesuatu yang akan diukur oleh kuesioner tersebut. Metode yang digunakan untuk menguji validitas adalah melakukan korelasi antar skor butir pertanyaan dengan total skor konstruk atau variabel. Uji signifikansi dilakukan dengan membandingkan $r_{\text {hitung }}$ dengan $r_{\text {tabel }}$ maka indikator dinyatakan valid dan sebaliknya jika $r_{\text {tabel }}$ lebih kecil dari pada $r_{\text {hitung }}$ maka indikator dinyatakan tidak valid.

\subsubsection{Uji Reliabilitas}

Suliyanto (2011:136), uji reliabilitas sebenarnya adalah alat untuk mengukur suatu kuesioner yang merupakan indikator dari variabel atau konstruk. Suatu kuesioner dikatakan reliabel atau handal jika jawaban seseorang terhadap pernyataan adalah konsisten atau stabil dari waktu ke waktu.

\subsection{Analisis Inferensial}

Sesuai dengan model penelitian yang dikembangkan, maka alat analisis inferensial yang cocok adalah menggunakan metode Structural Equation Modeling (SEM), yang langkah-langkah operasinya sebagai berikut:

\subsubsection{Uji Asumsi}

Untuk menjamin kesempurnaan pengunaan alat analisis statistika inferensial, secara teoritik dibutuhkan beberapa asumsi yang harus dipenuhi, setidak-tidaknya ada tiga asumsi yang harus dipenuhi, yaitu data yang dianalisis berdistribusi normal, tidak ada gejala mutikolinearitas dari seluruh data dari variabel eksogen dan tidak ada gejala heteroskedastisitas dari data yang dianalisis.

\subsubsection{Uji Normalitas Data}

Data dinyatakan berdistribusi normal jika data tersebar di sekitar garis diagonalnya. Sedang penggunaan pendekatan nilai $\mathrm{Z}$ Kolmogorov Smirnov atau Shapiro-Wilk, bahwa suatu data dinyatakan berdistribusi normal jika harga taraf signifikansi yang dihasilkan dari pengujian lebih besar dari 0.05. Sebaliknya, jika taraf signifikansi lebih kecil dari 0.05 maka disimpulkan data tidak berdistribusi normal. 


\section{1). Uji Non Multicolinearity}

Multikolinearitas adalah terjadinya hubungan yang signifikan (nyata) antara variabel bebas yang satu dengan variabel bebas yang lainnya, dan hal seperti itu dalam penggunaan SEM tidak diperbolehkan. Dengan kata lain bahwa secara individu tidak boleh terjadi pengaruh atau hubungan antar variabel bebas. Alat analisis yang dapat digunakan untuk mendeteksi ada tidaknya gejala multikoliaritas adalah dengan menggunakan harga dari Varians Inflation Factor (VIF). Jika dalam perhitungan dihasilkan harga VIF kurang 10, maka disimpulkan bahwa tidak ada gejala multikoliniaritas antar variabel bebas.

2). Uji Non Heteroscedasticity

Heteroskedastisitas adalah gejala munculnya ketidaksamaan harga varians dari residual pada pengamatan yang satu ke pengamatan yang lain. Asumsi yang diperlukan adalah tidak adanya gejala heteroskedastisitas.
Deteksi terhadap ada tidaknya gejala heteroskedastisitas dapat dilakukan dengan menggunakan Uji Glejser. Uji Glejser adalah teknik pengujian dengan cara meregresikan data dari setiap variabel bebas dengan harga absolut residualnya. Hipotesis pengujiannya adalah :

Ho : Tidak terjadi heteroskedastisitas

$\mathrm{H}_{1}$ : Terjadi heteroskedastisitas

Jika dari perhitungan dihasilkan harga taraf signifikansi > 0.05 maka Ho diterima, artinya data yang dianalisis tidak mempunyai gejala heteroskedastisitas.

\subsection{Pengembangan Diagram Jalur}

Sesuai dengan kerangka berpikir yang telah dipaparkan sebelumnya, dan juga sesuai dengan kerangka konseptual untuk konfirmatori setiap variabel, maka secara keseluruhan diagram jalur yang menunjukkan adanya hubungan dari satu variabel ke variabel yang lain dapat dilihat pada Gambar 1. berikut ini.

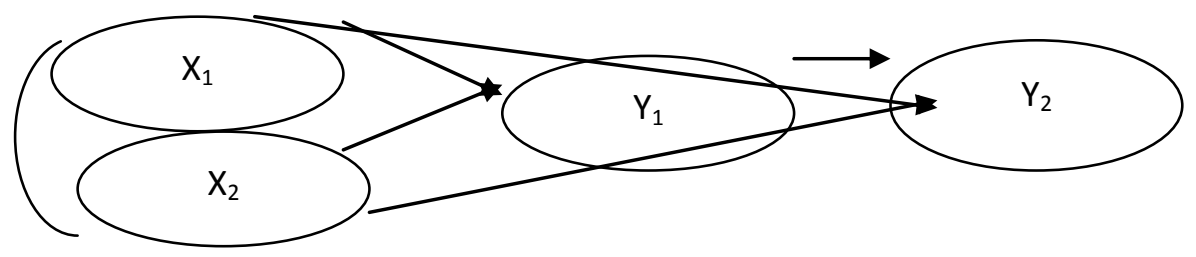

Gambar 1. Diagram analisis jalur

Dari gambar konseptual model penelitian tersebut, dapat disusun model strukturnya (structural model) sebagai berikut :

$\mathrm{Y}_{1}: \mathrm{b}_{1} \mathrm{X}_{1}+\mathrm{b}_{2} \mathrm{X}_{2}$

$Y_{2}: b_{1} X_{1}+b_{2} X_{2}+b_{3} Y_{1}$

Langkah-langkah dalam menggunakan analisis jalur (path analisys) (Sarwono, 2007:174) :

1) Menentukan model diagram jalurnya berdasarkan penelitian anda.
2) Menentukan diagram jalur persamaan strukturnya.

3) Menganalisis dengan menggunakan SPSS yang terdiri dari dua langkah, yaitu : analisis untuk substruktur 1 dan analisis untuk substruktur 2.

Untuk menyelesaikan analisis jalur maka perlu mengetahui adanya path diagram maupun path coefficients (koefisien jalur). Model analisis jalur disajikan sebagai berikut :

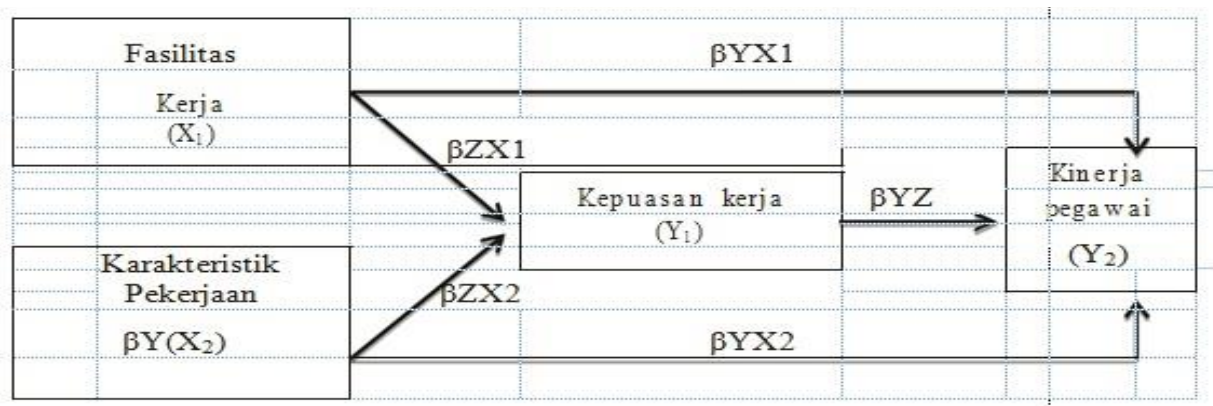

Gambar 2. Model Analisis Jalur (Path Analysis) 
Keterangan :

$\beta Z \mathrm{X} 1=$ Koefisien jalur pengaruh langsung fasilitas kerja $\left(\mathrm{X}_{1}\right)$ terhadap kepuasan kerja $\left(\mathrm{Y}_{1}\right)$.

$\beta Z \mathrm{X} 2=$ Koefisien jalur pengaruh langsung karakteristik pekerjaan $\left(\mathrm{X}_{2}\right)$ terhadap kepuasan kerja $\left(\mathrm{Y}_{2}\right)$.

$\beta Y X 1=$ Koefisien jalur pengaruh langsung fasilitas kerja $\left(\mathrm{X}_{1}\right)$ terhadap kinerja $\left(\mathrm{Y}_{2}\right)$.

$\beta Y X 2=$ Koefisien jalur pengaruh langsung karakteristik pekerjaan $\left(\mathrm{X}_{2}\right)$ terhadap kinerja pegawai $(\mathrm{Y})$.

$\beta Z \mathrm{ZY}=$ Koefisien jalur pengaruh langsung kepuasan kerja $\left(\mathrm{Y}_{1}\right)$ terhadap kinerja $\left(\mathrm{Y}_{2}\right)$.

\subsection{Uji Hipotesis (Uji t)}

Hipotesis adalah jawaban sementara terhadap suatu masalah. Jawaban tersebut masih perlu diuji kebenarannya, maka dari itu dilakukan uji hipotesis. Uji t digunakan untuk melihat signifikansi pengaruh dari variabel independen atau bebas $(\mathrm{X})$ secara individual (parsial) terhadap variabel dependen atau terikat (Y). Dengan kriteria pengujian :

1) Apabila $t_{\text {hitung }}>t_{\text {tabel }}$ berarti Ho ditolak dan Ha diterima. Artinya variabel bebas secara parsial memiliki pengaruh nyata terhadap variabel terikat. Hal ini berarti ada hubungan antara variabel fasilitas kerja dan karakteristik pekerjaan melalui kepuasan kerja terhadap kinerja pegawai.

2) Apabila $t_{\text {hitung }}<t_{\text {tabel }}$ berarti Ho diterima dan Ha ditolak. Artinya variabel bebas secara parsial tidak memiliki pengaruh nyata terhadap variabel terikat. Hal ini berarti tidak ada hubungan antara variabel fasilitas kerja dan karakteristik pekerjaan melalui kepuasan kerja terhadap kinerja pegawai.

\subsection{Menghitung Jalur (Trimming Theory)}

Perhitungan jalur menjelaskan hubungan fasilitas kerja $\left(\mathrm{X}_{1}\right)$ dan karakteristik pekerjaan $\left(\mathrm{X}_{2}\right)$ baik secara langsung ataupun tidak langsung terhadap kinerja $\left(\mathrm{Y}_{2}\right)$ melalui variabel intervening yaitu kepuasan kerja $\left(\mathrm{Y}_{1}\right)$. Sebelum menghitung jalur, sebaiknya diuji signifikansi masing-masing jalur yang telah ada. Apabila terdapat jalur yang tidak signifikan maka penggunaan model trimming perlu dilakukan yaitu model yang digunakan untuk memperbaiki suatu model struktur analisis jalur dengan cara mengeluarkan dari variabel eksogen yang koefisien jalurnya tidak signifikan. Cara menggunakan model trimming yaitu menghitung ulang koefisien jalur tanpa menyertakan variabel eksogen yang koefisien jalurnya tidak signifikan. Berikut merupakan proses perhitungan jalur dalam penelitian ini :

1. Menghitung pengaruh langsung (Direct Effect atau DE).

1) Pengaruh fasilitas kerja $\left(X_{1}\right)$ terhadap kepuasan kerja $\left(\mathrm{Y}_{1}\right)$.

$\mathrm{DE}_{\mathrm{xz} 1}=\mathrm{X}_{1} \rightarrow \mathrm{Y}_{1}$

2) Pengaruh karakteristik pekerjaan $\left(X_{2}\right)$ terhadap kepuasan kerja $\left(\mathrm{Y}_{1}\right)$

$\mathrm{DE}_{\mathrm{xz} 1}=\mathrm{X}_{2} \rightarrow \mathrm{Y}_{1}$

3) Pengaruh fasilitas kerja $\left(X_{1}\right)$ terhadap kinerja $\left(\mathrm{Y}_{2}\right)$. $\mathrm{DE}_{\mathrm{xz} 1}=\mathrm{X}_{1} \rightarrow \mathrm{Y}_{2}$

4) Pengaruh karakteristik pekerjaan $\left(X_{2}\right)$ terhadap kinerja $\left(\mathrm{Y}_{2}\right)$

$\mathrm{DE}_{\mathrm{xz} 1}=\mathrm{X}_{2} \rightarrow \mathrm{Y}_{2}$

5) Pengaruh kepuasan kerja $\left(Y_{1}\right)$ terhadap kinerja $\left(\mathrm{Y}_{2}\right)$ $\mathrm{DE}_{\mathrm{xz} 1}=\mathrm{Y}_{1} \rightarrow \mathrm{Y}_{2}$

2. Menghitung pengaruh tidak langsung (Inderrect Effect atau IE) :

a Pengaruh variabel fasilitas kerja $\left(\mathrm{X}_{1}\right)$ terhadap kepuasan kerja $\left(\mathrm{Y}_{1}\right)$ dan kinerja pegawai $\left(\mathrm{Y}_{2}\right) \mathrm{IE}_{\mathrm{xyz} 1}=\mathrm{X}_{1} \rightarrow \mathrm{Y}_{1} \rightarrow$ $\mathrm{Y}_{2}$

b. Pengaruh variabel karakteristik pekerjaan $\left(\mathrm{X}_{2}\right)$ terhadap kepuasan kerja $\left(\mathrm{Y}_{1}\right)$ dan kinerja pegawai $\left(\mathrm{Y}_{2}\right)$ $\mathrm{IE}_{\mathrm{xyz} 1}=\mathrm{X}_{2} \rightarrow \mathrm{Y}_{1} \rightarrow \mathrm{Y}_{2}$

\section{Hasil dan Pembahasan}

\subsection{Uji Validitas}

Uji validitas adalah uji statistik yang digunakan untuk menentukan seberapa valid suatu item pernyataan dalam mengukur variabel yang diteliti. Berikut ini hasil uji validitas dari keempat variabel yang diteliti.

Tabel 3

Out put uji vaiditas variabel fasilitas kerja

\begin{tabular}{|c|c|c|c|c|}
\hline Variabel & Angket & $r>0.3$ & Sig $<0.05$ & Keterangan \\
\hline Fasilitas & $X_{1.1}$ & 0.306 & 0.003 & Valid \\
\cline { 2 - 5 } $\begin{array}{c}\text { kerja } \\
\left(X_{1}\right)\end{array}$ & $X_{1.2}$ & 0.398 & 0.003 & Valid \\
\cline { 2 - 5 } & $X_{1.3}$ & 0.647 & 0.000 & Valid \\
\cline { 2 - 5 } & $X_{1.4}$ & 0.669 & 0.000 & Valid \\
\cline { 2 - 5 } & $X_{1.5}$ & 0.496 & 0.000 & Valid \\
\cline { 2 - 5 } & $X_{1.6}$ & 0.577 & 0.000 & Valid \\
\cline { 2 - 5 } & $X_{1.7}$ & 0.596 & 0.000 & Valid \\
\cline { 2 - 5 } & $X_{1.8}$ & 0.744 & 0.000 & Valid \\
\cline { 2 - 5 } & $X_{1.9}$ & 0.540 & 0.000 & Valid \\
\cline { 2 - 5 } & $X_{1.10}$ & 0.611 & 0.000 & Valid \\
\hline
\end{tabular}

Sumber : Hasil Pengolahan Data, 2019

Dari Tabel 3, di atas dapat dijelaskan bahwa nilai signifikansi butir-butir pernyataan untuk variabel fasilitas kerja keseluruhannya 
dinyatakan valid, karena nilai korelasinya lebih besar dari 0.3 dan nilai signifikansinya di bawah 0.05 .

Tabel 4

Out put uji vaiditas variabel karakteristik

pekerjaan

\begin{tabular}{|c|c|c|c|c|}
\hline Variabel & Angket & $r>0.3$ & Sig $<0.05$ & Keterangan \\
\hline Karakteristik & $X_{2.1}$ & 0.706 & 0.000 & Valid \\
\cline { 2 - 5 } $\begin{array}{c}\text { pekerjaan } \\
\left(X_{2}\right)\end{array}$ & $X_{2.2}$ & 0.662 & 0.000 & Valid \\
\cline { 2 - 5 } & $X_{2.3}$ & 0.417 & 0.000 & Valid \\
\cline { 2 - 5 } & $X_{2.4}$ & 0.618 & 0.000 & Valid \\
\cline { 2 - 5 } & $X_{2.5}$ & 0.564 & 0.000 & Valid \\
\cline { 2 - 5 } & $X_{2.6}$ & 0.408 & 0.000 & Valid \\
\cline { 2 - 5 } & $X_{2.7}$ & 0.652 & 0.000 & Valid \\
\cline { 2 - 5 } & $X_{2.8}$ & 0.405 & 0.000 & Valid \\
\cline { 2 - 5 } & $X_{2.9}$ & 0.573 & 0.000 & Valid \\
\cline { 2 - 5 } & $X_{2.10}$ & 0.679 & 0.000 & Valid \\
\hline
\end{tabular}

Sumber : Hasil Pengolahan Data, 2019

Dari Tabel 4, di atas dapat dijelaskan bahwa nilai signifikansi butir-butir pernyataan untuk variabel karakteristik pekerjaan keseluruhannya dinyatakan valid, karena nilai korelasinya lebih besar dari 0.3 dan nilai signifikansinya di bawah 0.05 .

Tabel 5

Out put uji vaiditas variabel kepuasan kerja

\begin{tabular}{|c|c|c|c|c|}
\hline Variabel & Angket & $r>0.3$ & Sig $<0.05$ & Keterangan \\
\hline $\begin{array}{c}\text { Kepuasan } \\
\text { kerja } \\
\left(Y_{1}\right)\end{array}$ & $Y_{1.1}$ & 0.605 & 0.000 & Valid \\
\cline { 2 - 5 } & $Y_{1.2}$ & 0.632 & 0.000 & Valid \\
\cline { 2 - 5 } & $Y_{1.3}$ & 0.541 & 0.000 & Valid \\
\cline { 2 - 5 } & $Y_{1.4}$ & 0.479 & 0.000 & Valid \\
\cline { 2 - 5 } & $Y_{1.5}$ & 0.361 & 0.000 & Valid \\
\cline { 2 - 5 } & $Y_{1.6}$ & 0.579 & 0.000 & Valid \\
\hline Variabel & Angket & $r>0.3$ & Sig $<0.05$ & Keterangan \\
\hline \multirow{5}{*}{} & $Y_{1.7}$ & 0.524 & 0.000 & Valid \\
\cline { 2 - 5 } & $Y_{1.8}$ & 0.662 & 0.000 & Valid \\
\cline { 2 - 5 } & $Y_{1.9}$ & 0.901 & 0.000 & Valid \\
\cline { 2 - 5 } & $Y_{1.10}$ & 0.615 & 0.000 & Valid \\
\hline
\end{tabular}

Dari Tabel 5, di atas dapat dijelaskan bahwa nilai signifikansi butir-butir pernyataan untuk variabel kepuasan kerja keseluruhannya dinyatakan valid, karena nilai korelasinya lebih besar dari 0.3 dan nilai signifikansinya di bawah 0.05 .

Tabel 6

Out put uji vaiditas variabel kinerja

\begin{tabular}{|c|c|c|c|c|}
\hline Variabel & Angket & $r>0.3$ & Sig $<0.05$ & Keterangan \\
\hline Kinerja & $Y_{2.1}$ & 0.625 & 0.000 & Valid \\
\cline { 2 - 5 } & $Y_{2.2}$ & 0.620 & 0.000 & Valid \\
\cline { 2 - 5 } & $Y_{2.3}$ & 0.573 & 0.000 & Valid \\
\cline { 2 - 5 } & $Y_{2.4}$ & 0.511 & 0.000 & Valid \\
\cline { 2 - 5 } & $Y_{2.5}$ & 0.412 & 0.000 & Valid \\
\cline { 2 - 5 } & $Y_{2.6}$ & 0.558 & 0.000 & Valid \\
\cline { 2 - 5 } & $Y_{2.7}$ & 0.579 & 0.000 & Valid \\
\cline { 2 - 5 } & $Y_{2.8}$ & 0.659 & 0.000 & Valid \\
\cline { 2 - 5 } & $Y_{2.9}$ & 0.891 & 0.000 & Valid \\
\cline { 2 - 5 } & $Y_{2.10}$ & 0.632 & 0.002 & Valid \\
\hline
\end{tabular}

Sumber : Hasil Pengolahan Data, 2019

Dari Tabel 6, di atas dapat dijelaskan bahwa nilai signifikansi butir-butir pernyataan untuk variabel loyalitas kerja keseluruhannya dinyatakan valid, karena nilai korelasinya lebih besar dari 0.3 dan nilai signifikansinya di bawah 0.05 .

\subsection{Uji Reliabilitas}

Uji reliabilitas adalah uji statistik yang digunakan untuk menentukan reliabilitas serangkaian item pernyataan dalam kehandalannya mengukur suatu variabel. Berikut ini hasil uji reliabilitas dari keempat variabel yang diteliti.

Tabel 7

Uji Reliabilitas

\begin{tabular}{|l|c|c|c|}
\hline \multicolumn{1}{|c|}{ Variabel } & $\begin{array}{c}\text { Nilai Alpha } \\
\text { Cronbach's }\end{array}$ & Reliabel/Tidak Reliabel & Keterangan \\
\hline Fasilitas Kerja $\left(\mathrm{X}_{1}\right)$ & 0.695 & Reliabel (Tinggi) & Dipakai \\
\hline Karakteristik Pekerjaan $\left(\mathrm{X}_{2}\right)$ & 0.761 & Reliabel (Cukup) & Dipakai \\
\hline Kepuasan Kerja $\left(\mathrm{Y}_{1}\right)$ & 0.866 & Reliabel (Tinggi) & Dipakai \\
\hline Kinerja $(\mathrm{Y})$ & 0.788 & Reliabel (Cukup) & Dipakai \\
\hline
\end{tabular}

Dari Tabel 7, diatas, diketahui nilai $\mathrm{r}_{\text {tabel }}$ untuk uji dua sisi pada tingkat signifikan 5\% $(\alpha=$ 0,05 ), dengan jumlah sample $\mathrm{N}=95$., maka derajat bebasnya adalah $\mathrm{N}-2=95-2=93$, dan diketahui nilai $r_{\text {tabel }}=0.210$. Dari hasil pengolahan data penelitian diperoleh nilai $r_{\text {hitung }}$ pada kolom cronbach's alpha if item deleted semua lebih besar dari nilai $r_{\text {tabel }}$, maka seluruh butir pernyataan untuk variabel dinyatakan reliabel.

\subsection{Pengujian Asumsi Klasik \\ 3.3.1.Uji Asumsi Normalitas}

Pada out put SPSS pada bagian Normal P-P Plot of Regresion Standardized Residual, dapat dijelaskan bahwa data-data (titik-titik) cenderung lurus mengikuti garis diagonal 
sehingga data dalam penelitian ini cenderung berdistribusi normal, seperti terlihat pada gambar dibawah ini.

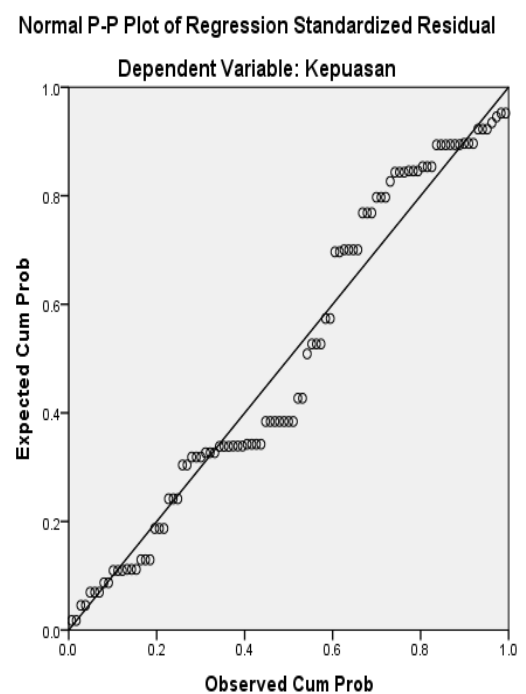

Gambar 3. Uji normalitas data variabel fasilitas kerja dan karakteristik pekerjaan terhadap kepuasan kerja

\subsubsection{Uji Heteroskedastisitas}

Pada output SPSS di bagian Scatterplot, terlihat titik-titik menyebar secara acak, tidak membentuk sebuah pola tertentu yang jelas, serta tersebar baik diatas maupun dibawah angka nol pada sumbu Y. Hal ini berarti tidak terjadi heteroskedastisitas pada model regresi, sehingga model regresi layak dipakai, dan dapat dilihat pada gambar dibawah ini :

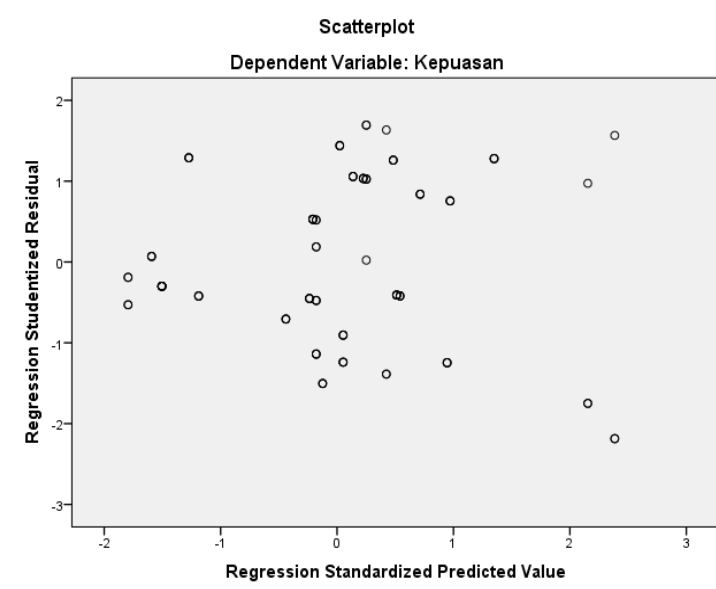

Gambar 4. Uji heteroskedastisitas variabel fasilitas kerja dan karakteristik pekerjaan terhadap kepuasan kerja

\subsubsection{Uji Multikolinieritas}

Dari Tabel 8, dapat dijelaskan bahwa nilai Collinearity Statistics untuk nilai Variance
Inflantion Factorrs (VIF) yang diperoleh dalam penelitian ini sebesar 1.080; 1.080, dan nilai tolerance sebesar 0.926 ; 0.926 ; dimana nilai Variance Inflantion Factorrs (VIF) dari kedua varibel bebas dalam penelitian ini lebih kecil dari 10 dan dapat disimpulkan tidak terjadi multikolinieritas diantara kedua variabel bebas dalam penelitian ini.

Tabel 8.

Uji asumsi multikolinieritas pengaruh fasilitas kerja dan karakteristik pekerjaan terhadap kepuasan kerja

\begin{tabular}{|l|r|c|}
\hline \multirow{2}{*}{ Variabel } & \multicolumn{2}{c|}{ Collinearity Statistics } \\
\cline { 2 - 3 } & Tolerance & \multicolumn{1}{c|}{ VIF } \\
\hline Fasilitas kerja & .926 & 1.080 \\
\hline Karakteristik pekerjaan & .926 & 1.080 \\
\hline a Dependent Variable : Kepuasan kerja
\end{tabular}

Dari Tabel 9, dapat dijelaskan bahwa nilai Collinearity Statistics untuk nilai Variance Inflantion Factorrs (VIF) yang diperoleh dalam penelitian ini sebesar 1.136; 1.140; 1.149, dan nilai tolerance sebesar 0.881; 0.877; 0.871 ; dimana nilai Variance Inflantion Factorrs (VIF) dari ketiga varibel bebas dalam penelitian ini lebih kecil dari 10 dan dapat disimpulkan tidak terjadi multikolinieritas diantara ketiga variabel bebas dalam penelitian ini.

Tabel 9

Uji asumsi multikolinieritas pengaruh fasilitas kerja dan karakteristik pekerjaan terhadap kepuasan kerja dalam meningkatkan kinerja

\begin{tabular}{|l|c|c|}
\hline \multirow{2}{*}{ Variabel } & \multicolumn{2}{c|}{ Collinearity Statistics } \\
\cline { 2 - 3 } & Tolerance & VIF \\
\hline Fasilitas kerja & .881 & 1.136 \\
\hline Karakteristik pekerjaan & .877 & 1.140 \\
\hline Kepuasan kerja & .871 & 1.149 \\
\hline a Dependent Variable : Kinerja &
\end{tabular}

\subsubsection{Uji Autokorelasi}

Berdasarkan Tabel 10, di atas diperoleh nilai statistik Durbin-Watson (DW) sebesar 2.305, nilai tersebut berada pada kisaran $1.65<$ DW < 2.35 maka dapat disimpulkan tidak terdapat autokorelasi pada model regresi dalam penelitian 
Tabel 10

Model summary ${ }^{\mathrm{b}}$ pengaruh fasilitas kerja dan karakteristik pekerjaan terhadap kepuasan kerja

\begin{tabular}{|l|r|r|r|r|r|r|}
\hline \multirow{4}{*}{ Model } & \multicolumn{5}{|c|}{ Change Statistics } & \multirow{2}{*}{$\begin{array}{c}\text { Durbin- } \\
\text { Watson }\end{array}$} \\
\cline { 2 - 7 } & $\begin{array}{c}\text { R Square } \\
\text { Change }\end{array}$ & F Change & df1 & df2 & $\begin{array}{c}\text { Sig. F } \\
\text { Change }\end{array}$ & \\
\hline 1 & .129 & 6.833 & 2 & 92 & .002 & 2.305 \\
\hline
\end{tabular}

a Predictors: (Constant), Fasilitas, Karakteristik

Dependent Variable: Kepuasan

Berdasarkan Tabel 11, di atas diperoleh nilai 2.35 maka dapat disimpulkan tidak terdapat statistik Durbin-Watson (DW) sebesar 2.034, autokorelasi pada model regresi dalam nilai tersebut berada pada kisaran $1.65<$ DW $<$ penelitian ini.

Tabel 11

Model summary ${ }^{\mathrm{b}}$ pengaruh fasilitas kerja dan karakteristik pekerjaan terhadap kepuasan kerja dalam meningkatkan kinerja

\begin{tabular}{|l|r|r|r|r|r|r|}
\hline \multirow{3}{*}{ Model } & \multicolumn{5}{|c|}{ Change Statistics } & \multirow{2}{*}{$\begin{array}{c}\text { Durbin- } \\
\text { Watson }\end{array}$} \\
\cline { 2 - 7 } & $\begin{array}{c}\text { R Square } \\
\text { Change }\end{array}$ & F Change & df1 & df2 & $\begin{array}{c}\text { Sig. F } \\
\text { Change }\end{array}$ & \\
\hline 1 & .689 & 67.290 & 3 & 91 & .000 & 2.034 \\
\hline
\end{tabular}

a Predictors: (Constant), Fasilitas, Karakteristik, Kepuasan

Dependent Variable: Kinerja

\subsection{Uji Analisis Jalur (Path Analysis)}

Uji t digunakan untuk melihat signifikansi pengaruh dari variabel independen atau bebas (X) secara individual (parsial) terhadap variabel dependen atau terikat (Y). Perhitungan jalur menjelaskan hubungan fasilitas kerja $\left(\mathrm{X}_{1}\right)$ dan karakteristik pekerjaan (X2) baik secara langsung ataupun tidak langsung terhadap kinerja pegawai $\left(\mathrm{Y}_{2}\right)$ melalui variabel intervening yaitu kepuasan kerja $\left(\mathrm{Y}_{1}\right)$.

Tabel 12

Hasil Uji Analisis Jalur Uji F Persamaan 1

ANOVA $^{\mathrm{a}}$

\begin{tabular}{|ll|r|r|r|r|l|}
\hline \multicolumn{1}{|l|}{ Model } & \multicolumn{1}{|c|}{$\begin{array}{c}\text { Sum of } \\
\text { Squares }\end{array}$} & df & Mean Square & F & Sig. \\
\hline \multirow{2}{*}{1} & Regression & 126.466 & 2 & 63.233 & 6.833 & $.002^{\mathrm{b}}$ \\
& Residual & 851.365 & 92 & 9.254 & & \\
& Total & 977.832 & 94 & & & \\
\hline
\end{tabular}

a. Dependent Variable: Kepuasan

b. Predictors: (Constant), Karakteristik, Fasilitas

Tabel 13

Hasil Uji Analisis Jalur Uji t Persamaan 1

\begin{tabular}{|c|c|c|c|c|c|}
\hline \multirow[t]{2}{*}{ Model } & \multicolumn{2}{|c|}{$\begin{array}{l}\text { Unstandardized } \\
\text { Coefficients }\end{array}$} & \multirow{2}{*}{$\begin{array}{c}\begin{array}{c}\text { Standardized } \\
\text { Coefficients }\end{array} \\
\text { Beta }\end{array}$} & \multirow[t]{2}{*}{$\mathrm{t}$} & \multirow[t]{2}{*}{ Sig. } \\
\hline & B & Std. Error & & & \\
\hline (Constant) & 24.280 & 5.013 & & 4.844 & .000 \\
\hline Fasilitas & .200 & .092 & .221 & 2.187 & .031 \\
\hline $\begin{array}{l}\text { Karakteristi } \\
\text { k }\end{array}$ & .234 & .103 & .230 & 2.275 & .025 \\
\hline
\end{tabular}


Tabel 14

Tabel 14. Hasil Uji Analisis Jalur Uji F Persamaan 2

\begin{tabular}{|ll|r|r|r|l|l|}
\hline \multicolumn{7}{|c|}{ ANOVA $^{\mathbf{b}}$} \\
\hline 1 & Regression & Sum of Squares & df & Mean Square & F & Sig. \\
\hline & 5.526 & 3 & 1.842 & 16.128 & $.000^{\mathrm{a}}$ \\
Residual & 8.795 & 77 & .114 & & \\
\multicolumn{1}{|l|}{ Total } & 14.321 & 80 & & & \\
\hline
\end{tabular}

a Predictors: (Constant), Fasilitas, Karakteristik, Kepuasan

Dependent Variable: Kinerja

Tabel 15

Hasil Uji Analisis Jalur Uji t Persamaan 2

\begin{tabular}{|c|c|c|c|c|c|c|}
\hline \multirow{2}{*}{\multicolumn{2}{|c|}{ Model }} & \multicolumn{2}{|c|}{ Unstandardized Coefficients } & \multirow{2}{*}{$\begin{array}{c}\begin{array}{c}\text { Standardized } \\
\text { Coefficients }\end{array} \\
\text { Beta }\end{array}$} & \multirow[t]{2}{*}{$\mathrm{t}$} & \multirow[t]{2}{*}{ Sig. } \\
\hline & & B & Std. Error & & & \\
\hline \multirow{4}{*}{1} & (Constant) & -3.716 & 3.481 & & -1.067 & .289 \\
\hline & Fasilitas & .319 & .058 & .341 & 5.476 & .000 \\
\hline & Karakteristik & .204 & .066 & 194 & 3.105 & .003 \\
\hline & Kepuasan & .589 & .065 & .570 & 9.107 & .000 \\
\hline
\end{tabular}

a Predictors: (Constant), Fasilitas, Karakteristik, Kepuasan

Dependent Variable: Kinerja

Berdasarkan hasil analisis pada tabel $5.20-$ 5.23, yaitu fasilitas kerja dan karakteristik pekerjaan berpengaruh positif dan signifikan terhadap kepuasan kerja pegawai. Begitu juga dengan fasilitas kerja, karakteristik pekerjaan dan kepuasan kerja berpengaruh positif dan signifikan terhadap kinerja pegawai dengan nilai signifikan $<0,05$.

Untuk penyelesaikan analisis jalur ini maka dapat digambarkan hasilnya sebagai berikut :

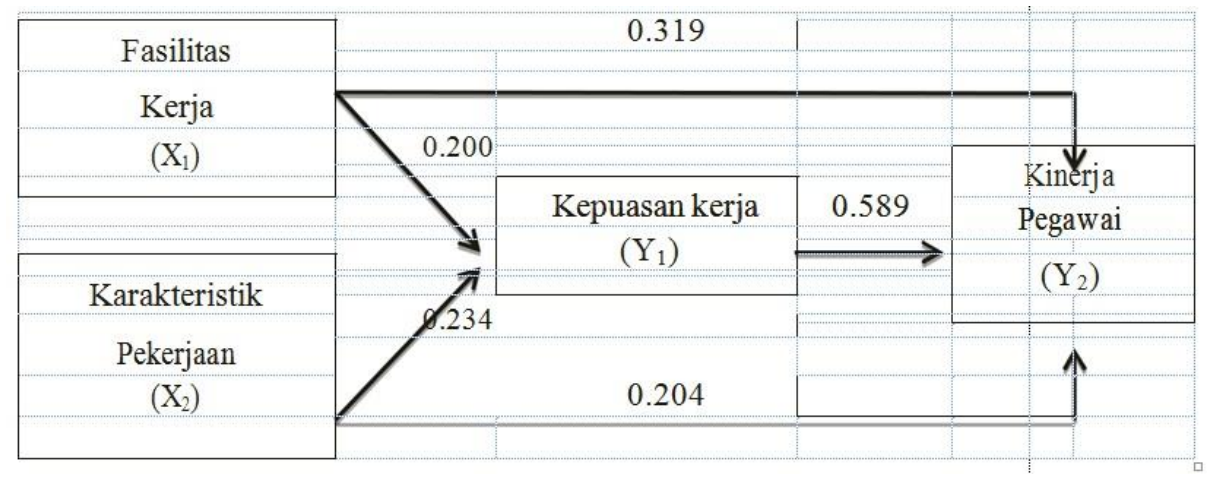

Gambar 5. Hasil Analisis Jalur (Path Analysis)

Dari hasil pengujian jalur maka dapat dinyatakan dalam model persamaan yang disajikan sebagai berikut :

$$
\begin{aligned}
& \text { Persamaan 1 : } \mathrm{Y}_{1}=0.200 \mathrm{X} 1+ \\
& 0.234 \mathrm{X} 2+\varepsilon 1 \\
& \text { Persamaan 2 }: \mathrm{Y}_{2}=0.247 \mathrm{X} 1+ \\
& 0.323 \mathrm{X} 2+0.219 \mathrm{Y}_{1}+\varepsilon 2
\end{aligned}
$$

\subsection{Menghitung Pengaruh Langsung (Direct} Effect atau DE)

a. Pengaruh variabel

fasilitas kerja $\left(\mathrm{X}_{1}\right)$ terhadap kepuasan $\operatorname{kerja}\left(\mathrm{Y}_{1}\right)$.

$$
\mathrm{DE}_{\mathrm{x} 1 \mathrm{y} 1}=\mathrm{X}_{1} \rightarrow \mathrm{Y}_{1}=0.200
$$

b. Pengaruh variabel karakteristik pekerjaan $\left(\mathrm{X}_{2}\right)$ terhadap kepuasan kerja $\left(\mathrm{Y}_{1}\right)$.

$$
\mathrm{DE}_{\mathrm{x} 2 \mathrm{y} 1}=\mathrm{X}_{2} \rightarrow \mathrm{Y}_{1}=0.234
$$

c. Pengaruh variabel fasilitas kerja $\left(\mathrm{X}_{1}\right)$ terhadap kinerja pegawai $\left(\mathrm{Y}_{2}\right)$.

$$
\mathrm{DE}_{\mathrm{x} 1 \mathrm{y} 2}=\mathrm{X}_{1} \rightarrow \mathrm{Y}_{2}=0.319
$$

d. Pengaruh variabel karakteristik pekerjaan $\left(\mathrm{X}_{2}\right)$ terhadap kinerja pegawai $\left(\mathrm{Y}_{2}\right)$.

$$
\mathrm{DE}_{\mathrm{x} 2 \mathrm{y} 2}=\mathrm{X}_{2} \rightarrow \mathrm{Y}_{2}=0.204
$$

e. Pengaruh variabel kepuasan kerja $\left(\mathrm{Y}_{1}\right)$ terhadap kinerja pegawai $\left(\mathrm{Y}_{2}\right)$. 


$$
\mathrm{DE}_{\mathrm{y} 1 \mathrm{y} 2}=\mathrm{Y}_{1} \rightarrow \mathrm{Y}_{2}=0.589
$$

3.6. Menghitung pengaruh tidak langsung (Inderrect Effect atau IE) :

a. Pengaruh variabel fasilitas kerja $\left(\mathrm{X}_{1}\right)$ terhadap kepuasan kerja $\left(\mathrm{Y}_{1}\right)$ dan kinerja pegawai $\left(\mathrm{Y}_{2}\right)$

$=(0.200)(0.589)$

$=0.118$

b. Pengaruh variabel karakteristik pekerjaan $\left(\mathrm{X}_{2}\right)$ terhadap kepuasan kerja $\left(\mathrm{Y}_{1}\right)$ dan kinerja pegawai $\left(\mathrm{Y}_{2}\right)$ $=(0.234)(0.589)$

$=0.138$

\subsection{Uji Hipotesis}

3.7.1. Pengaruh Fasilitas Kerja Terhadap

Kepuasan Kerja Pegawai di Kantor

Pelayanan Pajak Pratama Tebing

Tinggi.

Untuk mengetahui pengaruh fasilitas kerja terhadap kepuasan kerja pegawai di Kantor
Pelayanan Pajak Pratama Tebing Tinggi digunakan uji-t, dengan ketentuan sebagai berkut :

1) Jika nilai $t_{\text {hitung }}>t_{\text {tabel }}$ dan nilai probabilitas (p) $<$ tingkat signifikansi 5\% $(\alpha=0,05)$ maka hipotesis penelitian $\left(\mathrm{H}_{1}\right)$ diterima dan $\mathrm{H}_{0}$ ditolak, berarti ada pengaruh signifikan antara fasilitas kerja terhadap kepuasan kerja.

2) Jika nilai $t_{\text {hitung }}<t_{\text {tabel }}$ dan nilai probabilitas (p) > tingkat signifikansi 5\% $(\alpha=0,05)$ maka hipotesis penelitian $\left(\mathrm{H}_{1}\right)$ ditolak dan $\mathrm{H}_{0}$ diterima, berarti tidak ada pengaruh signifikan antara fasilitas kerja terhadap kepuasan kerja.

Penelitian ini menggunakan taraf signifikansi $(\alpha \quad 0,05)$ dan Derajat Kebebasan (DK) dengan ketentuan $\mathrm{DK}=\mathrm{n}-2$, atau $95-2$ $=93$. Dengan ketentuan tersebut, diperoleh nilai $\mathrm{t}_{\text {tabel }}$ sebesar 1.961 .

Tabel 16

Coeficients ${ }^{\mathrm{a}}$ pengaruh fasilitas kerja terhadap kepuasan kerja

\begin{tabular}{|c|c|c|c|c|c|c|}
\hline \multirow{2}{*}{\multicolumn{2}{|c|}{ Model }} & \multicolumn{2}{|c|}{$\begin{array}{l}\text { Unstandardized } \\
\text { Coefficients }\end{array}$} & \multirow{2}{*}{$\begin{array}{c}\text { Standardized } \\
\text { Coefficients } \\
\text { Beta }\end{array}$} & \multirow{2}{*}{$\mathrm{t}$} & \multirow{2}{*}{ Sig. } \\
\hline & & B & Std. Error & & & \\
\hline 1 & (Constant) & 24.280 & 5.013 & & 4.844 & .000 \\
\hline & Fasilitas kerja & .200 & .092 & .221 & 2.187 & .031 \\
\hline
\end{tabular}

a Dependent Variable : Kepuasan kerja

Hasil pengolahan data, 2019

Berdasarkan Tabel 5.24, out put SPSS "Coeficients" diatas diketahui nilai $t_{\text {hitung }}$ variabel fasilitas kerja sebesar 2.187. Karena nilai $t_{\text {hitung }}>t_{\text {tabel }}(2.187>1.961)$ dan nilai signifikasi $0.031<0.05$, sehingga $\mathrm{H}_{0}$ ditolak dan $\mathrm{H}_{1}$ diterima. Artinya hipotesis yang diajukan dalam penelitian ini diterima yaitu variabel fasilitas kerja secara partial berpengaruh positif dan signifikan terhadap kepuasan kerja pegawai di Kantor Pelayanan Pajak Pratama Tebing Tinggi. Hasil penelitian ini menjelaskan bahwa semakin baik fasilitas kerja maka semakin tinggi kepuasan kerja pegawai di Kantor Pelayanan Pajak Pratama Tebing Tinggi.

\subsubsection{Pengaruh Karakteristik Pekerjaan Terhadap Kepuasan Kerja Pegawai di Kantor Pelayanan Pajak Pratama Tebing Tinggi.}

Untuk mengetahui pengaruh karakteristik pekerjaan terhadap kepuasan kerja pegawai di
Kantor Pelayanan Pajak Pratama Tebing Tinggi digunakan uji-t, dengan ketentuan sebagai berkut :

1) Jika nilai $t_{\text {hitung }}>t_{\text {tabel }}$ dan nilai probabilitas (p) $<$ tingkat signifikansi 5\% $(\alpha=0,05)$ maka hipotesis penelitian $\left(\mathrm{H}_{1}\right)$ diterima dan $\mathrm{H}_{0}$ ditolak, berarti ada pengaruh signifikan antara karakteristik pekerjaan terhadap kepuasan kerja.

2) Jika nilai $t_{\text {hitung }}<t_{\text {tabel }}$ dan nilai probabilitas (p) > tingkat signifikansi 5\% $(\alpha=0,05)$ maka hipotesis penelitian $\left(\mathrm{H}_{1}\right)$ ditolak dan $\mathrm{H}_{0}$ diterima, berarti tidak ada pengaruh signifikan antara karakteristik pekerjaan terhadap kepuasan kerja.

Penelitian ini menggunakan taraf signifikansi $(\alpha \quad 0,05)$ dan Derajat Kebebasan (DK) dengan ketentuan $\mathrm{DK}=\mathrm{n}-2$, atau $95-2$ $=93$. Dengan ketentuan tersebut, diperoleh nilai $\mathrm{t}_{\text {tabel }}$ sebesar 1.961 . 
Tabel. 17

Coeficients ${ }^{\mathrm{a}}$ pengaruh karakteristik pekerjaan terhadap kepuasan kerja

\begin{tabular}{|c|c|c|c|c|c|c|}
\hline \multirow{2}{*}{\multicolumn{2}{|c|}{ Model }} & \multicolumn{2}{|c|}{$\begin{array}{c}\text { Unstandardized } \\
\text { Coefficients }\end{array}$} & \multirow{2}{*}{$\begin{array}{c}\text { Standardized } \\
\text { Coefficients } \\
\text { Beta }\end{array}$} & \multirow{2}{*}{$\mathrm{t}$} & \multirow{2}{*}{ Sig. } \\
\hline & & B & Std. Error & & & \\
\hline 1 & (Constant) & 24.280 & 5.013 & & 4.844 & .000 \\
\hline & $\begin{array}{l}\text { Karakteristik } \\
\text { pekerjaan }\end{array}$ & .234 & .103 & .230 & 2.275 & .025 \\
\hline
\end{tabular}

a Dependent Variable : Kepuasan kerja

Berdasarkan Tabel 5.25, out put SPSS "Coeficients" diatas diketahui nilai $t_{\text {hitung }}$ variabel karakteristik pekerjaan sebesar 2.275. Karena nilai $\mathrm{t}_{\text {hitung }}>\mathrm{t}_{\text {tabel }}(2.275>1.961)$ dan nilai signifikasi $0.025<0.05$, sehingga $\mathrm{H}_{0}$ ditolak dan $\mathrm{H}_{1}$ diterima. Artinya hipotesis yang diajukan dalam penelitian ini diterima yaitu variabel karakteristik pekerjaan secara partial berpengaruh positif dan signifikan terhadap kepuasan kerja pegawai di Kantor Pelayanan Pajak Pratama Tebing Tinggi. Hasil penelitian ini menjelaskan bahwa semakin baik karakteristik pekerjaan maka semakin tinggi kepuasan kerja pegawai di Kantor Pelayanan Pajak Pratama Tebing Tinggi.

\subsubsection{Pengaruh Fasilitas Kerja Terhadap Kinerja Pegawai di Kantor Pelayanan Pajak Pratama Tebing Tinggi.}

Untuk mengetahui pengaruh fasilitas kerja terhadap kinerja pegawai di Kantor Pelayanan Pajak Pratama Tebing Tinggi digunakan uji-t, dengan ketentuan sebagai berkut :

1) Jika nilai $t_{\text {hitung }}>t_{\text {tabel }}$ dan nilai probabilitas (p) $<$ tingkat signifikansi 5\% $(\alpha=0,05)$ maka hipotesis penelitian $\left(\mathrm{H}_{1}\right)$ diterima dan $\mathrm{H}_{0}$ ditolak, berarti ada pengaruh signifikan antara fasilitas kerja terhadap kinerja.

2) Jika nilai $t_{\text {hitung }}<t_{\text {tabel }}$ dan nilai probabilitas (p) > tingkat signifikansi 5\% $(\alpha=0,05)$ maka hipotesis penelitian $\left(\mathrm{H}_{1}\right)$ ditolak dan $\mathrm{H}_{0}$ diterima, berarti tidak ada pengaruh signifikan antara fasilitas kerja terhadap kinerja.

Penelitian ini menggunakan taraf signifikansi $(\alpha \quad 0,05)$ dan Derajat Kebebasan (DK) dengan ketentuan DK $=\mathrm{n}-2$, atau $95-2$ $=93$. Dengan ketentuan tersebut, diperoleh nilai $t_{\text {tabel }}$ sebesar 1.961 .

Tabel. 18

Coeficients ${ }^{\mathrm{a}}$ pengaruh fasilitas kerja terhadap kinerja

\begin{tabular}{|c|c|c|c|c|c|c|}
\hline \multirow{2}{*}{\multicolumn{2}{|c|}{ Model }} & \multicolumn{2}{|c|}{$\begin{array}{c}\text { Unstandardized } \\
\text { Coefficients }\end{array}$} & \multirow{3}{*}{$\begin{array}{c}\text { Standardized } \\
\text { Coefficients } \\
\text { Beta }\end{array}$} & \multirow{2}{*}{$\mathrm{t}$} & \multirow{2}{*}{ Sig. } \\
\hline & & B & Std. Error & & & \\
\hline 1 & (Constant) & -3.716 & 3.481 & & -1.067 & .289 \\
\hline & $\begin{array}{l}\text { Fasilitas } \\
\text { kerja }\end{array}$ & .319 & .058 & .341 & 5.476 & .000 \\
\hline
\end{tabular}

a Dependent Variable : Kinerja

Berdasarkan Tabel 5.26, out put SPSS "Coeficients" diatas diketahui nilai $t_{\text {hitung }}$ variabel fasilitas kerja sebesar 5.476. Karena nilai $t_{\text {hitung }}>t_{\text {tabel }}(5.476>1.961)$ dan nilai signifikasi $0.000<0.05$, sehingga $\mathrm{H}_{0}$ ditolak dan $\mathrm{H}_{1}$ diterima. Artinya hipotesis yang diajukan dalam penelitian ini diterima yaitu variabel fasilitas kerja secara partial berpengaruh positif dan signifikan terhadap kinerja pegawai di Kantor Pelayanan Pajak Pratama Tebing Tinggi. Hasil penelitian ini menjelaskan bahwa semakin baik fasilitas kerja maka semakin tinggi kinerja pegawai di Kantor Pelayanan Pajak Pratama Tebing Tinggi.

\subsubsection{Pengaruh Karakteristik Pekerjaan Terhadap Kinerja Pegawai di Kantor Pelayanan Pajak Pratama Tebing Tinggi.}

Untuk mengetahui pengaruh karakteristik pekerjaan terhadap kinerja pegawai di Kantor Pelayanan Pajak Pratama Tebing Tinggi 
digunakan uji-t, dengan ketentuan sebagai berkut :

1) Jika nilai $t_{\text {hitung }}>t_{\text {tabel }}$ dan nilai probabilitas (p) $<$ tingkat signifikansi 5\% $(\alpha=0,05)$ maka hipotesis penelitian $\left(\mathrm{H}_{1}\right)$ diterima dan $\mathrm{H}_{0}$ ditolak, berarti ada pengaruh signifikan antara karakteristik pekerjaan terhadap kinerja.

2) Jika nilai $t_{\text {hitung }}<t_{\text {tabel }}$ dan nilai probabilitas (p) $>$ tingkat signifikansi 5\% $(\alpha=0,05)$

Tabel. 19

Coeficients $^{\mathrm{a}}$ pengaruh karakteristik pekerjaan terhadap kinerja

\begin{tabular}{|c|c|c|c|c|c|c|}
\hline \multirow{2}{*}{\multicolumn{2}{|c|}{ Model }} & \multicolumn{2}{|c|}{$\begin{array}{c}\text { Unstandardized } \\
\text { Coefficients }\end{array}$} & \multirow{3}{*}{$\begin{array}{c}\text { Standardized } \\
\text { Coefficients } \\
\text { Beta } \\
\end{array}$} & \multirow{2}{*}{$\mathrm{t}$} & \multirow{2}{*}{ Sig. } \\
\hline & & B & Std. Error & & & \\
\hline 1 & (Constant) & -3.716 & 3.481 & & -1.067 & .289 \\
\hline & $\begin{array}{l}\text { Karakteristik } \\
\text { pekerjaan }\end{array}$ & 204 & .066 & .194 & 3.105 & .003 \\
\hline
\end{tabular}

a Dependent Variable : Kinerja

Berdasarkan Tabel 5.27, out put SPSS "Coeficients" diatas diketahui nilai $t_{\text {hitung }}$ variabel fasilitas kerja sebesar 3.105. Karena nilai $t_{\text {hitung }}>t_{\text {tabel }}(3.105>1.961)$ dan nilai signifikasi $0.003<0.05$, sehingga $\mathrm{H}_{0}$ ditolak dan $\mathrm{H}_{1}$ diterima. Artinya hipotesis yang diajukan dalam penelitian ini diterima yaitu variabel karakteristik pekerjaan secara partial berpengaruh positif dan signifikan terhadap kinerja pegawai di Kantor Pelayanan Pajak Pratama Tebing Tinggi. Hasil penelitian ini menjelaskan bahwa semakin baik karakteristik pekerjaan maka semakin tinggi kinerja pegawai di Kantor Pelayanan Pajak Pratama Tebing Tinggi.

\subsubsection{Pengaruh Kepuasan Kerja Terhadap Kinerja Pegawai di Kantor Pelayanan Pajak Pratama Tebing Tinggi.}

Tabel. 20

Untuk mengetahui pengaruh kepuasan kerja terhadap kinerja pegawai di Kantor Pelayanan Pajak Pratama Tebing Tinggi digunakan uji-t, dengan ketentuan sebagai berkut :

1) Jika nilai $t_{\text {hitung }}>t_{\text {tabel }}$ dan nilai probabilitas (p) $<$ tingkat signifikansi 5\% $(\alpha=0,05)$ maka hipotesis penelitian $\left(\mathrm{H}_{1}\right)$ diterima dan $\mathrm{H}_{0}$ ditolak, berarti ada pengaruh signifikan antara kepuasan kerja terhadap kinerja.

2) Jika nilai $t_{\text {hitung }}<t_{\text {tabel }}$ dan nilai probabilitas (p) > tingkat signifikansi 5\% $(\alpha=0,05)$ maka hipotesis penelitian $\left(\mathrm{H}_{1}\right)$ ditolak dan $\mathrm{H}_{0}$ diterima, berarti tidak ada pengaruh signifikan antara kepuasan kerja terhadap kinerja.

Penelitian ini menggunakan taraf signifikansi $(\alpha \quad 0,05)$ dan Derajat Kebebasan (DK) dengan ketentuan $\mathrm{DK}=\mathrm{n}-2$, atau $95-2$ $=93$. Dengan ketentuan tersebut, diperoleh nilai $\mathrm{t}_{\text {tabel }}$ sebesar 1.961 .

Coeficients $^{\mathrm{a}}$ pengaruh kepuasan kerja terhadap kinerja

\begin{tabular}{|c|c|c|c|c|c|c|}
\hline \multirow{2}{*}{\multicolumn{2}{|c|}{ Model }} & \multicolumn{2}{|c|}{$\begin{array}{c}\text { Unstandardized } \\
\text { Coefficients }\end{array}$} & \multirow{2}{*}{$\begin{array}{c}\text { Standardized } \\
\text { Coefficients } \\
\text { Beta } \\
\end{array}$} & \multirow{2}{*}{$\mathrm{t}$} & \multirow{2}{*}{ Sig. } \\
\hline & & $\mathrm{B}$ & Std. Error & & & \\
\hline \multirow[t]{2}{*}{1} & (Constant) & -3.716 & 3.481 & & -1.067 & .289 \\
\hline & $\begin{array}{l}\text { Kepuasan } \\
\text { kerja }\end{array}$ & .589 & .065 & .570 & 9.107 & .000 \\
\hline
\end{tabular}

a Dependent Variable : Kinerja

Berdasarkan Tabel 5.28, out put SPSS "Coeficients" diatas diketahui nilai $\mathrm{t}_{\text {hitung }}$ variabel fasilitas kerja sebesar 9.107. Karena nilai $\mathrm{t}_{\text {hitung }}>\mathrm{t}_{\text {tabel }}(9.107>1.961)$ dan nilai signifikasi $0.000<0.05$, sehingga $\mathrm{H}_{0}$ ditolak dan $\mathrm{H}_{1}$ diterima. Artinya hipotesis yang 
diajukan dalam penelitian ini diterima yaitu variabel kepuasan kerja secara partial berpengaruh positif dan signifikan terhadap kinerja pegawai di Kantor Pelayanan Pajak Pratama Tebing Tinggi. Hasil penelitian ini menjelaskan bahwa semakin tinggi kepuasan kerja maka semakin tinggi kinerja pegawai di Kantor Pelayanan Pajak Pratama Tebing Tinggi.

\section{Kesimpulan}

1. Fasilitas kerja berpengaruh positif dan signifikan terhadap kepuasan kerja pegawai di Kantor Pelayanan Pajak Pratama Tebing Tinggi.

2. Karakteristik pekerjaan berpengaruh positif dan signifikan terhadap kepuasan kerja pegawai di Kantor Pelayanan Pajak Pratama Tebing Tinggi.

3. Fasilitas kerja berpengaruh positif dan signifikan terhadap kinerja pegawai di Kantor Pelayanan Pajak Pratama Tebing Tinggi.

4. Karakteristik pekerjaan berpengaruh positif dan signifikan terhadap kinerja pegawai di Kantor Pelayanan Pajak Pratama Tebing Tinggi.

5. Kepuasan kerja berpengaruh positif dan signifikan terhadap kinerja pegawai di Kantor Pelayanan Pajak Pratama Tebing Tinggi.

\section{DAFTAR PUSTAKA}

Apri Dahliur \& Mariaty Ibrahim (2016), Pengaruh fasilitas kerja terhadap kepuasan kerja pegawai pada PT. bank Riau Kepri Cabang Teluk Kuantan Kabupaten Kuantan Singingi, JOM, FISIP, Vo. 3 No. 2.

Cascio, Wayne F.,( (2006) Managing Human Resources: Productivity, Quality of Work Life, Profits, edition, New York, McGraw Hill

Colquitt, J. A., LePine, J. A., and Wesson., (2009) Organizational Behavior: Improving Performance and Commitment in the Workplace, New York, McGraw Hill, pp. 37

Cross, T.M dan Lynch. R.R. (2006). Peniliaian dan Evaluasi Kinerja: Konsep dan Praktik. Jakarta. Penerbit Ghalia Indonesia

Dessler, Garry (2007), Manajemen Sumber Daya Manusia, PT. Preshelindo, Jakarta.

Firman (2011), Pengaruh karakteristik pekerjaan terhadap kepuasan kerja pegawai di lingkungan Pemkot Payakumbuh, TANGKAP, Vol. 7 No. 2

Fisher, Martin, (2005), Performance Appraisals, Kogan Page Limited

Goleman, Daniel, (2008), Emotional Intelligence, Cetakan keenambelas, terjemahan, Gramedia

Handoko T, Hani (2010), Manajemen Personalia dan Sumber Daya Manusia, Edisi Kedua, BPFE Yogyakarta.

Hasibuan, Malayu, SP (2008), Manajemen Sumber Daya Manusia, PT. Bumi Akasara Jakarta.

Ishak Arep, dan Hendri Tanjung. 2004. Manajemen Motivasi. Grasindo, Jakarta.

Isnan Munawirsyah (2017), Pengaruh kepuasan kerja dan fasilitas kerja terhadap motivasi kerja dan dampaknya terhadap kinerja pegawai non medis pada RSUD Kota Subulussalam, Jurnal Bisnis Administrasi, Vol. o6 Nomor : 01, 2017; 44-51.

Khoirun Anam \& Edy Rahardja (2017), Pengaruh fasilitas kerja, lingkungan kerja non fisik dan kepuasan kerja terhadap kinerja (Studi pada pegawai Dinas Perindustrian dan Perdagangan Provinsi Jawa Tengah, Diponegoro Journal of Management Vo. 6 Nomor 4 Tahun 2017, Hal 1-11.

Mangkunegara, Anwar, Prabu. (2009). Evaluasi Kinerja SDM, Cetakan 4, Bandung : Refika Aditama

Milkovich, T George and Newman, Jerry M, (2008), Competency, Mc Graw Hill International Edition

Murphy, S. E., and Pirozzolo, F. J., (2002) Multi Journal ple Intelligences and Leadership, New Jersey, Lawrence Erlbaum

Nitisemito S Alex (2009), Manajemen Personalia, Cetakan Keempat, Ghalia, Jakarta.

Purwanto, Ngalim (2003), Psikologi Instansi. Bandung : PT. Remaja Rosdakarya

Rivai, Veithzal dan Sagala, Ella Jauvani. (2009). Manajemen Sumber Daya Manusia Untuk Organisasi : Dari Teori ke Praktek. Jakarta : PT. Rajagrafindo Persada

Rizal Eka Affandi (2016), Pengaruh karakteristik pekerjaan terhadap kinerja pegawai dengan motivasi dan lingkungan kerja sebagai variabel pemoderasi (Studi pada pegawai Divisi Sarana PT. Kereta Api Indonesia (Persero) DIop * Surabaya, JIRE, Vol. 7 No. 2 
Robbins P. Stephen, Coulter Mary alih bahasa oleh Benyamin, (2009), Manajemen, Edisi keenam, Jilid 2, PT. Indeks Jakarta

Santoso, Singgih (2004), SPSS Statistik Parametrik, PT. Alex Media Komputindo, Kelompok Gramedia Jakarta.

Sedarmayanti. (2009), Good Governance (Kepemerintahan Yang Baik), Bandung : Mandar Maju

Sink, R dan Tuttle, J.K. (2008). Evaluasi Kinerja. Jakarta: Indeks Kelompok Gramedia

Sugiyono (2004), Metode Penelitian, Erlangga Surabaya

Triton PB (2005), Paradigma Baru Manajemen Sumber Daya Manusia, Tugu Yogyakarta
(2006), SPSS 13,00 Terapan, Riset Statistik Parametrik, Andi, Yogyakarta Wahjosumidjo (2005), Kepemimpinan dan Motivasi, Liberty Yogyakarta

Wibowo, (2007), Manajemen Kinerja. Cetakan Pertama. Jakarta: Raja Grafindo Persada.

Wilson Bangun (2006), Pengaruh karakteristik pekerjaan terhadap kepuasan kerja dan komitmen organisasi serta dampaknya pada produktivitas kerja pegawai (Survei pada pegawai industry tekstil Provinsi Jawa Barat), Sosiohummaniora, Vol. 8 No. 2 . 